\title{
Sexbots as Synthetic Companions: Comparing Attitudes of Official Sex Offenders and Non-Offenders
}

\author{
Georgia Zara ${ }^{1,2}$ (D) Sara Veggi ${ }^{1}$ (D) David P. Farrington ${ }^{2}$ (i)
}

Accepted: 4 June 2021 / Published online: 1 July 2021

(c) The Author(s) 2021

\begin{abstract}
This is the first Italian study to examine views on sexbots of adult male sex offenders and non-offenders, and their perceptions of sexbots as sexual partners, and sexbots as a means to prevent sexual violence. In order to explore these aspects 344 adult males were involved in the study. The study carried out two types of comparisons. 100 male sex offenders were compared with 244 male non-offenders. Also, sex offenders were divided into child molesters and rapists. Preliminary findings suggest that sex offenders were less open than non-offenders to sexbots, showed a lower acceptance of them, and were more likely to dismiss the possibility of having an intimate and sexual relationship with a sexbot. Sex offenders were also less likely than non-offenders to believe that the risk of sexual violence against people could be reduced if a sexbot was used in the treatment of sex offenders. No differences were found between child molesters and rapists. Though no definitive conclusion can be drawn about what role sexbots might play in the prevention and treatment of sex offending, this study emphasizes the importance of both exploring how sexbots are both perceived and understood. Sex offenders in this study showed a high dynamic sexual risk and, paradoxically, despite, or because of, their sexual deviance (e.g. deficits in sexual self-regulation), they were more inclined to see sexbots as just machines and were reluctant to imagine them as social agents, i.e. as intimate or sexual arousal partners. How sex offenders differ in their dynamic risk and criminal careers can inform experts about the mechanisms that take place and can challenge their engagement in treatment and intervention.
\end{abstract}

Keywords Sexbots $\cdot$ Synthetic relationships $\cdot$ Sex offending $\cdot$ Sexual deviance $\cdot$ Treatment

\section{Introduction}

Sexbots are humanoid sex robots that "resemble humans in features that are relevant for sexual interaction" [1, p. 2]. Turkle and colleagues [2] speak of sexbots as relational artefacts that not only do things for us, but do things to us. According to Cox-George and Bewley [3], sexbots no longer represent a caricature or a disguise of the human being, or a futuristic reality. Sexbots are relational artifacts [4] with whom people tend to form emotional bonds [2], and see them as having 'states of mind', so that an understanding of those states enriches human encounters with them. While sexbots have entered the personal lives of people, invaded

Georgia Zara

georgia.zara@unito.it

1 Department of Psychology, Università degli Studi di Torino, Turin, Italy

2 Institute of Criminology, University of Cambridge, Cambridge, United Kingdom their psychological imagination, and been involved in professional activities such as rehabilitation, sex care services, and selecting company staff, the meaning of a sexbot is, to a certain extent, still controversial $[5,6]$.

Some controversy surrounds the emotional reactions that sexbots arouse.

According to the Uncanny Valley Theory [7], there exists a non-linear relationship between human realism and a tendency to relate to another individual, so that an uneasy feeling seems to emerge when viewing a nonhuman character that looks nearly human. It is from the adverb 'nearly' that flourishes a sense of strangeness that makes people wary. As androids or robots become more humanlike and people feel more curious about them, then at the same time it seems that their human appearance elicits both fascination and eeriness, along with a sense of unfamiliarity. Research $[8,9]$ shows that when a robot becomes highly humanlike, people still know that there is something unreal about it. In a survey carried out with the "Robotics" section at the Swiss National Exhibition Expo.02 [10], 47\% of the individuals 
interviewed did not prefer a robot with human appearance. Similar results were found in other studies in which participants managed to imagine easily a robot as a machine, but not as a human robot [11]. In an experimental study, the interaction of individuals with both less-human and more human-like robots had an anthropomorphizing effect upon subsequent behavior (a sort of primacy effect) and led them to associate various human-like traits to robots [12]. Humanoid robots were perceived as more credible than the less humanoid variant. However, there was a cross-over effect: individuals were more likely to trust the judgements of a less humanoid robot if they had previously interacted with a more humanoid variant, but their trust in human-like robots reduced after having interacted with a less humanlike variant.

Reactions to sexbots have emerged from different scientific fields (e.g. ethics, philosophy, law, psychology, clinical rehabilitation, and many others).

A scoping review carried out by Döring, Mohseni, and Walter [13], on the design, use, and effects of sex-dolls and sexbots, showed that most of the empirical studies they reviewed ( 8 out of $12,67 \%$ ) were small web-based surveys on sexbot acceptance. The studies used convenience samples (from United States, Indonesia, and Malaysia), and showed that rates of sexbot acceptance varied. For example, $40 \%$ of male and $17 \%$ of female respondents in the United States reported willingness to try out a sexbot $[13,14]$ in comparison with $16 \%$ of Indonesian respondents [15] and $9 \%$ of Malaysian respondents [16].

Cultural background, male gender, positive attitudes toward technology in general, sensation seeking, and shyness appeared to be predictors of sexbot acceptance [13]. Interestingly, sexual and relationship satisfaction did not predict sexbot acceptance [17]. In their review, Döring and colleagues [13] reported that six out of ninety-eight sexbot studies covered child sexbots. These studies [18-22] advocated that sexbots were harmful and unethical, and one study specifically called for legal action [21]. Only two studies speculated on the possible therapeutic use of child sexbots, stressing that this exploration would be too risky [23], and that the employment of sexbots should only be allowed in controlled circumstances and under strict medical supervision [18].

\section{The Controversial Scientific "Sexbots" Debate}

The more human a sexbot looks like, the greater the bond that could be created with it because people are inclined to attribute to that sexbot psychological characteristics and mental states and intentions (i.e. theory of mind) [24]. There are sexbots programmed to develop a particular personality, to be able to have a conversation, to conserve a memory of what happened in communication exchanges, to hint at a smile, to indicate their disapproval, to show interest towards their interlocutor, and to express a preference. These are aspects that are considered important in interpersonal relationships and which, until recently, were seen as the prerogative of human beings alone and, as such, not reproducible. Scientific research [25] is offering examples of how many more human features can be simulated by increasingly sophisticated, humanized technological artefacts.

Some scholars [26] advocate that sexbots cast some doubts on the meaning of being 'human' and at the same time challenge any reflection on what a relationship is or should be, what is expected from a partner [27], and what type of sexuality can be possible with a robot [28]. Though one can speculate that the sexuality shared with a sexbot could have some arousal effects similar to those enhanced by the use of pornography, an involvement with a humanlike sexbot could have a stronger impact because of the role played by physically interacting with a sexbot that looks and sounds «almost» like a human. Research findings suggest that sexbots seem to benefit some individuals who find it difficult to have a fulfilling emotional and sexual life because of their social isolation, lack of interpersonal skills, sexual inadequacy, or because they are lonely, physically disabled, or elderly [29]. Introducing sexbots into the sexual space that exists between partners, with their desires and their fantasies, can have unexpected effects. Sexbots may, in fact, alter the very concept of intimacy, to the extent that it becomes something artificial, almost synthetic, or simply mechanical [30].

Some may argue that sexbots might be useful for treating sex offenders, individuals with sexual dysfunctions, and also paedophiles [31]. Given the present lack of evidence on the therapeutic effects of sexbots, it is strongly suggested to look carefully at the use of sexbots in the treatment of sex offenders, who are likely to have specific criminogenic needs that require specific scientific and clinical consideration (e.g. sexual deviance, sexual self-regulation difficulties, intimacy deficits, sexualized aggression, etc.).

The use of sexbots as an outlet and the possibility of employing them in the treatment of sex offenders cannot be reduced to a moral versus immoral acceptancy [32]. Using simulations of adult-child sex or adult-adult sex can be scientifically acceptable if it allows for testing other possibilities of treating sex offenders and preventing sexual abuse from persisting. Before stepping into the idea that sexbots are the theory, and sex-offending against women and children is the practice [33], more research is demanded to test this assumption.

Two lines of thoughts best synthetize the issues concerning sexbots. 
Some arguments in favour of the 'fostering sociality' hypothesis claim that sexbots will help to reduce social and emotional isolation [34], to treat relationship difficulties and erectile dysfunction, and to encourage withdrawn or differently able people to experience intimacy and sexuality, which may otherwise remain remote and unfulfilled needs for them [5]. Studies [35-37] suggest that individuals who have some impediments against having a fulfilled sexual life could benefit from sexbots. Loneliness could be one of the reasons for prompting adults to make alternative choices for finding a sexual companion [38]. Furthermore, there may be situations in which individuals prefer to use a sexbot to fulfil their sexual needs and desires and, according to Eggleton [39], there is no reasonable argument to suggest that this choice is unacceptable or problematic per se.

Another line of argument addresses the 'harm limitation' hypothesis by stating that sexbots will help to divert the deviant sexual interests of the sex offenders away from children and women to sexbots, so as to reduce the likelihood of sexual offences against children and women [40]. Roboticists seem to be the most favorable because they foresee the progress of robots in medical areas such as rehabilitation and social reintegration, while experts in the field of sex-offending seem the most critical. Since Ronald Arkin in 2014 suggested that child molesters, with paedophilic dispositions, could be treated with an integrated psychological therapy including the use of sexbots [see [28]], the use of sexbots with sex offenders constitutes the most controversial aspect of applied robotic research [41], dividing the scientific community.

For some, sexbots are more likely to distort ideas about sexuality because they are likely to encourage sexually deviant fantasies. For instance, if a child sexbot becomes a preferential sexual subject for a sex offender, no-one could claim that this type of sexual life would remain exclusive. It is possible that the sexual fantasy of having sex with a child might enhance the curiosity to try this with a real child, so as to intensify the physical and sexual interest by exploring this act in place of the sexbot [3]. No certain evidence is available on these aspects though. Various researchers [42, 43] suggest that fantasies play a significant role in sexuality: studies involving pornography or virtual reality, as an experimental setting to explore sexuality, have shown that realistic potentially gratifying responses could be evoked both in sexually deviant and non-deviant men, and that in many cases the sexual fantasy was gratifying in itself [44].

\section{Sexbots and Sexual Fantasy}

Imagination and fantasy affect human relationships [45] in all their forms and modalities. Fantasies have been defined by Schlesinger [46] as a group of symbols synthesized into a unified story, representing the result of the experiences that individuals have had and what they see, feel, desire, undergo and hear [47]. These fantasies may also be a substitute for action or, as Beres [48] suggests, may prepare the way for action in the future.

Sexual fantasies serve to animate thinking by images and sensations; the responses can be both emotional and physiological, without necessarily making the effort to disturb behavior [49]. Sexual fantasies offer, in fact, a more complete descriptive picture of individual sexuality than sexual behavior does, in that the latter is necessarily filtered, or, in any case, conditioned by norms and conventions. This is why sexuality could not exist in a culture without words, without images, lacking metaphors and symbols to represent it [50]. Sexual fantasies offer a window that opens up to the world of innermost desires which one would not necessarily attempt to fulfil, but whose elaboration is sufficient to offer a sense of playful and erotic gratification [51].

Howitt [52] maintains that, in officially prosocial individuals, fantasies make up a separate dominion that contributes to sexual arousal, but does not guide behavior, while in sex offenders the link between fantasy and behavior is more complex, and it is likely that it is the sexually abusive behavior that feeds sexual fantasies, and not the other way around $[49,53]$. A distorted thought or fantasy does not necessarily lead to antisocial acts [54].

However, it is particularly difficult to study sexual fantasies directly. Well trained clinicians argued that very seldom do their patients speak openly about their sexual fantasies or inner-sexual thoughts or desires [55], and this applies more so when working with sex offenders. Studies show that sex offenders are particularly reticent in expressing their views about their sexual fantasies, and they rarely recognize the sexual nature of their offenses [56]. The violation of sexuality that led to their conviction is often denied, or explained by them as "something that did not have anything to do with who they are". When they admitted it, it was "something that just happened" [57].

Clinical studies are unanimous in suggesting that sexual fantasies could have a vicarious sexual role and be a means to arouse and sexually satisfy [58]. Sexbots could be thought of as promoting surrogate sex-activities as pornography does. They could also become a useful substitute for actual sexual contact, and could serve as a tool for many sex offenders that helps them to redirect their urges and drives, in a way that does not involve having sex with children or a nonconsensual woman [59]. Seen in this way, sexbots could be effective in a prevention protocol against sex offending.

As with most studies investigating the prevalence of Internet child pornography consumption, studies on child sexbots speculate on an important practical question of whether consumers of sexbots pose a risk for hands-on sex offenses. Research on pornography seen as a sex-activity surrogate, 
can help to suggest the impact that sexbots could have upon the increased risk for sexual abuse. Studies on the accessibility to child pornography in specific countries have not suggested that this leads to an increase of child sex abuse. Even though this could be explained by the dark omen that affects it, Diamond and colleagues [60] found that when the Czech Republic lifted, in 1989, its ban on pornography, including child pornography, there was a decrease in rape and child sexual abuse. Similar findings were obtained in Japan, China, and United States [61]. These results are also in line with the findings from an earlier Danish study [62].

Riegel [59] explored the effects on 290 boy-attracted pedosexual males of viewing boy erotica. The interest was to see whether the consumption of child pornographic material exacerbated the tendency for these males to seek out boys for sexual purposes. $84.5 \%$ of men involved in the survey responded that either rarely or never had they had an increased tendency to act on their sexual deviant urges on children. When the nature of the images was 'abusive nonconsensual', only $16.9 \%$ described those images as attractive, while $69 \%$ of the participants described the images as disturbing, and $14.1 \%$ defined them as unattractive.

Similar results were found when exploring the impact of pornography on sexual abuse of women. Bridges and colleagues [63] analyzed 304 scenes from best-selling pornography videos. $88.2 \%$ of scenes contained physical aggression (e.g. spanking, gagging, slapping), while $48.7 \%$ of scenes contained verbal aggression (e.g. name-calling). It was interesting for the researchers to observe that depictions of rape or scenes that perpetuated the "rape myths" "were absent. On the contrary, nearly all of the women involved expressed enjoyment. Bridges and colleagues [63] concluded that to a certain extent consumers of pornography may share the view that aggression during sexual encounters is pleasure-enhancing for both men and women, and this may endorse scenes in which the sexual arousal emerges when willingness even for sexualized aggressiveness is shared rather than imposed. This might have some implications for discouraging sexual aggression, though increasing benevolent sexism $[66,67]$ and the objectification of human beings [30].

Two assumptions emerge from these findings. If the assumption is that sexual fantasies do not necessarily have to turn into behavior, the hypothesis that sexbots might play a significant role in vicariously satisfying sexual needs follows from these views. If this were the case, then those sex offenders who have developed sexual fantasies towards a sexbot might be less likely to act out these fantasies sexually

\footnotetext{
1 Rape myths are false beliefs and biased attitudes about rape that are used to deny and/or justify male sexual aggression against women. These myths are based on male dominance for which women enjoy and desire coercive, physically forced, and nonconsensual sex [for details see $[64,65]]$.
}

towards a child or a non-consenting person. Shin Takagi, a self-defined paedophile and artist, is the owner of the company Trottla, which has long produced child-like sexbots, which resemble young girls far less than ten years old. The basic idea behind his production is that, because it is impossible to modify people's sexual and fetishist inclinations, sexbots help people express and manifest their desires legally, without getting involved in dangerous, compromising or legally dubious situations [68].

A different assumption suggests that sexual fantasies elicited by sexbots may exacerbate the likelihood of sexual assault and rape of real children and adults. The availability on the market of sexbots which are programmed to say "no" or to resist the partner's sexual advances is now a reality [69]. What is most surprising is not the fact that technology has worked to create this type of robot, but that these sexbots are in the market and used in everyday life by many different buyers, and not necessarily sex offenders $[21,70]$. Sexbot Frigid Farrah ${ }^{2}$ presents the features of the woman who is frigid and encourages whoever interacts with her to rape her. Young Yoko (just 18) is very naïve, curious, and just waiting to learn, while Mature Martha conveys the idea of a woman as a supportive companion who likes holding the hands of her partner [71]. Any of these sexbots can have built in them a customized personality based on individual preferences and needs.

\section{Current State of Research}

Beyond the clinical implications on the use of sexbots in treating sex offenders, some crucial issues must be taken into account. The first is related to how sexbots are perceived by people in general, and by sex offenders in particular: can sexbots be seen as something to have a sexual interaction and relationship with? If yes, this might be a step forward in the promotion of alternative relationships.

The second issue is concerned with the meanings that sexbots convey. Do sexbots contribute to promote images of women or men as sexual objects, or of children as sexual commodities? If this is so, sexbots might foster beliefs that the value of a person depends on some sexually enhanced characteristics, customized characteristics, and that the ideal partner is the one who responds to the commands of others.

The third issue involves the so called "switch mechanism" [53]. Can sexbots become a means to switch deviant or obscure sexual desires away from real to imagined others? If, on the one hand, this switch mechanism may prevent more people from being sexually abused, on the other hand,

\footnotetext{
${ }^{2}$ Frigid Farrah can be purchased at the price of $\$ 9,995$. Cfr. http:// www.truecompanion.com/shop/faq
} 
such an approach may contribute to only a temporary switch and, at the same time, it may reinforce deviant fantasies and desires.

According to their creator [40], redirecting 'dark desires' is what sexbots can do. There is no evidence that sexbots will constitute a barrier against sexual abuse [72, 73], nor is there evidence that they will exacerbate the risk [53]. Sexbots might only have the temporary effect of diverting a person's sexual interest from human beings.

Due to the variance in findings, more research is necessary to explore whether sexbots endorse or dispel the myth that sexbots are a means of acting out one's fantasies. Clinical studies tell us that there may be a risk that high exposure to simulated deviant sexuality and violence leads to a normalization of these attitudes. Hence there is no certainty that these deviant attitudes will turn out to become deviant behavior. For some the deviant fantasies might act as a container to satisfy their imagination, while for others these fantasies may become less appealing and eventually lead to them seeking real life victims. It is up to researchers to explore the differential risk posed by different sex offenders [56].

There is no doubt that scientific research has the primary aim of preventing (e.g. ensuring that new people do not fall into abusive traps and that victims are not (re)victimized) and treating (e.g. ensuring that sex offenders receive intervention according to their criminogenic needs and their level of risk). However, mental health professionals, as Cox-George and Bewley [3] advocate, must be prepared for the inevitable questions about the impact of sexbots on society in general, and on well-being and psychological and relational health specifically [74]. The use of sexbots in the treatment and rehabilitation of sex offenders has inevitable consequences at the individual, social, and legal levels that must be examined and not ignored.

Very little is known about the effects of sexbots on sexual life, on the sexual needs of sex offenders and, also, on how sex offenders themselves perceive the use of sexbots as a feasible opportunity in their treatment. Studies suggest that sex offenders can respond to treatment [75-77], and evidencebased programs are welcomed into the clinical setting. However, to the best of our knowledge no study has investigated the extent to which sexbots are known and accepted as possible sexual companions by sex offenders themselves.

The paucity of evidence-based information surrounding this topic should not be used as a justification for not raising, exploring and discussing the issue of sexbots in the treatment of sex offenders, as there will be consequences for individuals and society, as already anticipated by some [3, $53,74,78]$. This seems a significant first step in understanding the ethical implications of endorsing a device in the most intimate dimension of human life (i.e. sexuality), with the complication of exploring this in a specific population (i.e. sex offenders).

\section{Empirical Questions}

Some questions are addressed in this study:

Can people imagine themselves in an intimate and sexual relationship with a sexbot?

Are there any differences between male sex offenders and non-offenders in their views about sexbots?

What do sex offenders think about employing sexbots as a means to prevent sexual violence?

\section{The Study}

In order to explore the views on sexbots of adult male sex offenders and non-offenders, a study was designed to gather direct information on the topic. Given the debate of using sexbots in the treatment of sex offenders, some specific questions (see above) about the possible use of them in preventing sexual violence were included, along with the assessment of cognitive distortions and social desirability. The sexual risk and the criminal careers of sex offenders were analyzed in order to differentiate between different types of sex offenders (child molesters and rapists).

\section{Method}

\subsection{Variables}

\subsubsection{Measures}

Six measures and a clinical interview were employed in this study.

\subsubsection{SexBot Questionnaire (SBQ)}

The SexBot Questionnaire (SBQ) [53] was designed to explore the social perceptions of sexbots and the level of openness in interacting and having a relationship with them, and in regarding them as a possible means for treatment. The SBQ is made up of 3 parts. The first part introduces the theme of sexbots and asks participants whether they are aware of sexbots being available in the market. Four images of sexbots, ${ }^{3}$ portraying two adult sexbots (a man and a woman) and two child sexbots (a boy and a girl), are used to ask participants to report the degree of preference on a scale from 0 (not at all attractive) to 100 (very attractive). The

\footnotetext{
3 The choice of sexbots was based on the results of a pilot study in which a sample of adult people were asked to express their preferences over a set of images of sexbots. All images of the sexbots presented in this study were adjusted to meet the research aims.

The girl sexbot was inspired by Satomi: http://www.orient-doll.com/
} 
images were the medium by which participants could get access to sexbots. These images displayed sexbots available in the market, and were chosen and adapted to show mainly their faces so as to limit external or background suggestions. In human relationships faces are considered of extreme significance [79]. The interest here was in fact to gather responses mostly based on what participants imagined by looking at the photos. Other experiments on robots have focused attention on their facial features and their humanlikeness $[24,80]$, rather than on other aspects of the robots [81], because it was established that faces are an informative aspect to assess the acceptability of robots [79].

In the second part, participants are asked to indicate their degree of interest in having a sexbot (for instance also by receiving it as a gift), their sexual attraction towards the pre-chosen sexbot, and the concrete possibility of having an intimate relationship with the sexbot, marking their answers along a continuum from 0 to 100 . The final part investigates whether the use of sexbots in the treatment of sex offenders could be a reasonable avenue to explore, whether sexual violence performed towards a robot is more acceptable than sexual violence against a person, and whether sexbots could contribute to lowering the risk of violence against people. The SBQ showed good internal consistency (Cronbach's Alpha $\alpha=0.72 ; 95 \% \mathrm{CI}=0.67-0.76$ ).

\subsubsection{Social Desirability}

Social desirability is the tendency to 'fake good' by making a desirable impression on others and presenting oneself in a favorable light [82]. This is mostly done to elicit approval and consensus, and it can be self-enhanced in those situations in which the person is under assessment (e.g. job interview), diagnosis (e.g. mental health unit) or judgment (e.g. criminal courts, prisons) [83]. There is no doubt that socially desirable responding (SDR) can threaten the validity of selfreports. The Marlowe-Crowne Social Desirability Scale (MC) [84] was originally developed to measure a person's tendency to distort self-presentation toward a socially desirable bias. In addition to this original 33-item MC, several short forms have been developed and researched. The short

\section{Footnote 3 (continued)}

\section{en/gallery/images/satomi/satomi_06_1.jpg}

The boy sexbot was inspired by the work of Mark Sagar at the Laboratory for Animate Technologies, Auckland Bioengineering Institute: www.abi.auckland.ac.nz/en/about/our-research/animate-technologies. html

The woman sexbot was inspired by some sexbots used in a Campaign Against Sex Robots: https://www.abc.net.au/news/2016-11-25/ anti-sex-robot-campaign-warns-of-danger-to-women-and-children/ 8023224

The man sexbot was inspired by Gabriel:

https://www.phillymag.com/news/2015/01/07/life-size-realisticmale-sex-dolls-sinthetics-man-will-never-leave/ form of the MC social desirability scale (MC-C) is a 13-item two-point (false $=0$; true $=1$ ) version, developed by Reynolds [85]. This version is used in the present study. Previous studies showed that it has good psychometric properties, and has internal consistency ranging from 0.62 to 0.76 [85-87]. It has already been used in criminological and forensic settings [88]. Items include: «I sometimes feel resentful when I don't get my way», «I sometimes try to get even rather than forgive and forget» and «I have never deliberately said something that hurt someone's feelings».

\subsubsection{Bumby Molest and Bumby Rape Scales}

The Bumby Molest and Rape Scales [89] are self-reported scales and were originally designed to measure the cognitive distortions and sexual fantasies of men who sexually assault children (the MOLEST scale) and women (the RAPE scale), by using a four-point Likert scale ( $1=$ strongly disagree; $4=$ strongly agree). The Bumby Molest is made up of 38 items and assesses attitudes and cognitive distortions relating to child molestation. Items include: «Having sexual thoughts and fantasies about a child isn't all that bad because at least it is not really hurting the child», «It is better to have sex with one's child than to cheat on one's wife», «Some people are not "true" child molesters; they are just out of control and made a mistake» and «Some kids like sex with adults because it makes them feel wanted and loved».

The Bumby Rape is made up of 36 items and assesses cognitive distortions and sexual fantasies relating to rape. Items include: «If women did not sleep around so much, they would be less likely to get raped», «A lot of women claim they were raped just because they want attention», «If a woman does not resist strongly to sexual advances, she is probably willing to have sex» and «Women who get raped will eventually forget about it and get on with their lives».

An important advantage of these scales is that they have been used both in correctional settings to assess sex offenders (e.g. Nebraska Department of Corrections; California's Sex Offender Commitment Programme) and in treatment to measure changes in cognition before and after treatment (e.g. Atascadero State Hospital-ASH) [90]. These scales have also been used with other types of offenders (e.g. violent and non-violent offenders) [91] and in community samples [92], since different studies have highlighted how distorted thinking can be present, in various forms, in all people.

\subsubsection{Criminal Career Diversity}

Few studies have attempted to understand the criminal careers of sex offenders $[56,93]$ in prospective longitudinal samples [94], in adult sex offenders [95], and in juveniles involved in sex offenses [96, 97]. The criminal career paradigm (CCP) [98] provides a framework to assist in 
understanding the way patterns of sexual offending relate to patterns of nonsexual offending; whether sex offenders are specialized (i.e. tend to commit only one particular type of crime) or heterogeneous in their offending (i.e. tend to commit offenses of various types). With the concept of criminal careers is meant in this study the official previous crimes and convictions attributed to the individual perpetrator, as indicated in the forensic files examined [99]. We are aware that this is only a partial perspective of what a criminal career is [100-102].

\subsubsection{Sexual Risk}

The level of sexual risk of the sex offenders was assessed with the Static-99R, Static2002R, and Stable-2007.

The Static-99R [103-105] is a 10-item actuarial risk assessment instrument that measures the static risk for sexual and/or violent reoffending posed by adult male sexual offenders convicted of at least one sexual offense against a non-consenting adult or child. The Static-99R gathers data on three areas regarding an offender: Demographic information (e.g. age), criminal history (e.g. past sexual offenses), and victim information (e.g. any male victims or any stranger victims) [106]. The total score can range from -3 to 12. The Static-99R has shown good predictive validity for sexual, violent, and general criminal recidivism (area under the receiver operating curve $(\mathrm{AUC})=0.68,0.70$, and 0.72 , respectively) [107].

The Static2002R $[108,109]$ is an actuarial risk assessment instrument for adult male sex offenders, and is used to integrate the assessment of static risk. The scale has 14 items grouped into five main subscales: age at release (1 item), persistence of sex offending ( 3 items), sexual deviance (3 items), relationship to victims ( 2 items), and general criminality (5 items).

The Stable-2007 [110] is a measure of risk-relevant propensities for the supervision and treatment of adult males charged or convicted for sex crimes. It is designed to assess and track changes in risk levels over time by assessing 13 dynamic risk factors that form five subscales (i.e. Significant Social Influences; Intimacy Deficits; Sexual Self-Regulation; General Self-Regulation; Cooperation with Supervision). The total score ranges from 0 to 26. The Stable-2007 has been shown to be a strong predictor of sexual recidivism $(\mathrm{AUC}=0.76)[110]$.

\subsubsection{Clinical Interview}

Semi-structured interviews were conducted to gather information about offenders' childhood and adulthood experiences that were relevant to understanding their sexual life, family and intimate relationships, and criminal careers. A clinical psychologist carried out each individual interview, which was video recorded, transcribed verbatim, and lasted two to three hours.

\subsection{Data Collection and Information for the Study}

\subsubsection{Procedures}

Participation in this research was on a voluntary basis. Participants were provided information about the purpose of the study, what participation entailed, and the confidentiality of their information. Participants signed the informed consent form, acknowledging that the procedures of the study had been explained to them, and that they understood that they could withdraw from the study at any time without consequence. Participants were also informed that the contents of the interviews and the exchanges during the assessment tasks were completely confidential and that under no circumstances what was disclosed by them would be made public or used to inform the criminal justice system (see Ethical approval).

Licenced psychologists had previously received training in the administration of the Static-99R, Static-2002R and Stable-2007 measures and completed the measures for this study. In this study, two psychologists independently completed these measures for the whole sample $(n=100)$. For the Static-99R, the interrater reliability was high: $\mathrm{ICC}_{2,2}=0.854$, with 95\% CI [0.809-0.892]. For the Static2002R, the interrater reliability was high: $\mathrm{ICC}_{2,2}=0.867$, with 95\% CI [0.825-0.902]. For the Stable-2007, the interrater reliability was also high: $\mathrm{ICC}_{2,2}=0.854$, with $95 \% \mathrm{CI}$ [0.792-0.905]. When a discrepancy emerged, they discussed the case and re-assessed it, until a better level of agreement was reached.

The psychologists were not informed of the criminal careers of the sample prior to the interview. This precaution allowed them to approach the interview setting without any preconception regarding the seriousness of the crimes or the dangerousness of the offender [56]. It was also believed that this would facilitate openness and would foster a climate of trust between the psychologist and the sex offender that is essential in order to develop a professional alliance [111] and reciprocal acceptance [112]. Official criminal records were gathered from the criminal justice system by another researcher who did not meet the participants.

\section{Sample}

The sample was composed of 344 adult males. 100 were convicted sex offenders (experimental group), and 244 were individuals who were non-offenders (control group) of whom 75 individuals made up a matching control sample (individuals with the same socio-demographic features 
as the sex offenders, apart from involvement in a criminal career). Because the sex offenders in the sample were males, the analysis in this study only includes adult males.

The average age of sex offenders was 45.61 years old $(S D=13.22)$, with on average over 9 years of education $(\underline{\mathrm{M}}=9.57 ; S D=4.26)$. The majority of them was Italian $(n=60 ; 60 \%) .82 \%$ of them $(n=82)$ were professionally occupied, while $18 \%(n=18)$ were unemployed. On the basis of the national classification of professions by ISTAT (National Statistics Institute), $61 \%$ of sex offenders $(n=61)$ were involved in a non-qualified profession (e.g. cleaner) or semi-qualified one (e.g. truck-driver), and $21 \%(n=21)$ in a qualified profession (e.g. teacher). $71 \%(n=71)$ of the sex offenders were married or involved in an intimate relationship at the time of the crime. After their conviction, $63 \%$ $(n=63)$ of them were separated or single.

On the basis of the criminological and forensic material gathered, it was possible to identify that 256 persons were the direct victims of the sex offenders in the study, but this is just an estimate, that the forensic files highlighted, because it was plausible to hypothesize that there was a significant number of never-discovered abuses and never-identified victims. The median average age of the identified victims was 14 years, in a range of between 6 months and 64 years. Most of the victims $(86.0 \% ; n=86)$ were female and $69.0 \%$ $(n=69)$ of them knew their aggressor. In $42.0 \%(n=42)$ of the cases, the abuse occurred in a family context and in $14.0 \%(n=14)$ of the cases it was incest. $34 \%$ of offenders $(n=34)$ were involved in intimate partner violence (IPV).

Two hundred and forty-four prosocial individuals were involved in the study as a control group, with an average age of 41.30 years $(S D=14.77)$, and an average education level of 13 years of study $(\underline{\mathrm{M}}=13.31 ; S D=3.85)$. Most of them were Italian $(n=219 ; 89.8 \%) .53 .3 \%(n=130)$ of the prosocial individuals were involved in a qualified profession, and $21.7 \%(n=53)$ had a non-qualified job, while $25 \%(n=60)$ were students or unemployed people. $68 \%(n=166)$ were involved in a romantic relationship at the time of participation in the study.

\section{Analytical Strategy}

Descriptive analyses were carried out to explore the social perception of sexbots in the psychological reality of sex offenders and official non-offenders, and to assess the criminal careers of sex offenders. Multivariate analyses included a between-individual comparison between sex offenders and non-offenders, and 75 sex offenders versus 75 matched control non-offenders, who were matched case-by-case on demographic and psychosocial variables. A second wave of multivariate analyses was involved a between-individual comparison of child molesters versus rapists.

To established preferences for sexbots, responses were dichotomized at the fourth-quartile. Despite some controversies regarding over-artificial categorization versus continuous variables, some supportive work on employing dichotomization is available [113]. Dichotomization also simplifies the presentation of results, makes it possible to compare the predictive strengths of variables, and equalizes the sensitivity of their measurement $[114,115]$. Odds ratios were calculated to identify which factors significantly predicted group differences (e.g. sex offenders versus non-offenders). Odds ratios provide information about the existence, direction, and strength of a difference between target and comparison groups regarding the likelihood of an event occurring [114].

\section{Results}

\subsection{Sex Offenders and Non-Offenders}

As described in the sample section, sex offenders were older than non-offenders $t(342)=-2.652, p=0.010,(d=0.31)$ [116], and had a lower level of education $t(342)=7.941$, $p=0.001,(d=0.92)$. However, no difference was found in unemployment between sex offenders $(n=18 ; 18 \%)$ and nonoffenders $(n=61 ; 25 \%)$ (OR: $0.659 ; 95 \% \mathrm{CI}=0.37-1.1)$.

The 75 matching control non-offenders were similar to their sex offender counterparts, in age $t(148)=0.300$, $p=0.764, \quad(d=0.05)$, education $t(148)=-0.318$, $p=0.751,(d=0.05)$, and employment (OR: 1.000; $95 \%$ $\mathrm{CI}=0.42-2.39)$, confirming that they were matched accurately.

\subsection{Social Desirability}

As expected, and in line with previous studies, the level of social desirability of sex offenders was significantly higher than for non-offenders. However, no significant difference was found when 75 sex offenders were compared with their matched-control counterparts. Table 1 shows these findings.

\subsection{Cognitive distortions}

Contrary to expectations, no differences were found in the levels of cognitive distortions involving children as a preferable focus of interaction, when comparing sex offenders with non-offenders. Similarly, no differences were found when comparing sex offenders with non-offenders regarding cognitive distortions towards women (see Table 1 for details).

These findings were replicated when comparing cognitive distortions towards children in a subsample of 52 sex offenders, and 52 matched non-offenders. The level of cognitive 
Table 1 Sex offenders versus non-offenders on social desirability and cognitive distortions

\begin{tabular}{|c|c|c|c|c|}
\hline \multirow[t]{2}{*}{ Psychosocial variables } & \multicolumn{2}{|l|}{ Sample categories } & \multicolumn{2}{|l|}{$T$-test $(d f)$} \\
\hline & Sex offenders (A) $n=100$ & Non-offenders (B) $n=244$ & $\mathrm{~A} / \mathrm{B}$ & Cohen's $d$ \\
\hline Social desirability & $\underline{\mathrm{M}}=7.99 ; S D=2.87$ & $\underline{\mathrm{M}}=6.60 ; S D=2.56$ & $t(319)=-4.315, p=.0001$ & 0.51 \\
\hline $\begin{array}{l}\text { Cognitive distortions towards children (Bumby } \\
\text { Molest) }\end{array}$ & $\underline{\mathrm{M}}=49.68 ; S D=12.86$ & $\underline{\mathrm{M}}=48.10 ; S D=12.30$ & $t(168)=-.805, p=.21$ & 0.13 \\
\hline $\begin{array}{l}\text { Cognitive distortions towards women (Bumby } \\
\text { Rape) }\end{array}$ & $\underline{\mathrm{M}}=57.13 ; S D=15.50$ & $\underline{\mathrm{M}}=56.51 ; S D=15.33$ & $t(170)=-2.59, p=.39$ & 0.04 \\
\hline Psychosocial variables & Sex offenders (A) $n=75$ & Matched-control (C) $n=75$ & $\mathrm{~A} / \mathrm{C}$ & Cohen's $d$ \\
\hline Social desirability & $\underline{\mathrm{M}}=7.55 ; S D=2.94$ & $\underline{\mathrm{M}}=6.68 ; S D=2.81$ & $t(147)=1.856, p=.065$ & 0.30 \\
\hline $\begin{array}{l}\text { Cognitive distortions towards children (Bumby } \\
\text { Molest) }\end{array}$ & $\underline{\mathrm{M}}=50.20 ; S D=14.51$ & $\underline{\mathrm{M}}=47.42 ; S D=12.48$ & $t(96)=-1.017, p=.16$ & 0.21 \\
\hline $\begin{array}{l}\text { Cognitive distortions towards women (Bumby } \\
\text { Rape) }\end{array}$ & $\underline{\mathrm{M}}=57.56 ; S D=16.48$ & $\underline{\mathrm{M}}=60.92 ; S D=16.86$ & $t(98)=1.007, p=.16$ & 0.20 \\
\hline
\end{tabular}

Because of the delicate topic examined, when comparing matched sex offenders with matching-control for the cognitive distortions only 52 individuals were involved for each group

distortion towards women was lower in the 52 sex offenders in comparison with 52 matched non-offenders though not significantly different.

\subsubsection{Previous Knowledge of Sexbots}

Sex offenders and non-offenders were asked whether they had ever heard about sexbots, and from which source. Half of the sample $(n=49 ; 50.0 \%)$ of sex offenders seemed to have heard of sexbots, and to know of their availability in the market. Similar answers were also given by the nonoffenders ( $n=142 ; 58.2 \%$ ) (see Table 2 for these findings). The majority of participants in this study acknowledged the existence of sexbots entering the Western world via social networks, newspapers or television $(n=172 ; 90.1 \%)$.

\subsection{Choosing Sexbots}

Findings suggest that the woman sexbot was, comparatively, the most preferred one: $67.3 \%(n=66)$ of the sex offenders expressed their appreciation for it, and 57\% $(n=139)$ of non-offenders showed the same preference for the woman sexbot (see Table 2 for details). However, when asked to express their choice for a specific sexbot, sex offenders were more likely to dismiss any particular preference towards any sexbot (either child sexbots or adult sexbots), and this was so for both the child molesters and the rapists involved in the study. It was different for the non-offenders in the sample, who seemed more willing to express their preferences and to show curiosity about sexbots. The likelihood of a woman sexbot being found attractive and be chosen was not significantly different between sex offenders and non-offenders. On the contrary, the girl sexbot was less likely to be chosen by sex offenders than non-offenders. A man sexbot was less likely to be found attractive and chosen by sex offenders than non-offenders. Similarly the boy sexbot was less likely to be chosen by sex offenders than non-offenders.

When 75 sex offenders were compared with the 75 matched non-offenders, the results showed that the matched non-offenders more openly expressed their preferences towards all the sexbots presented to them, in comparison with 75 matched sex offenders. Specifically, it was almost three times more likely that the girl sexbot was considered attractive and chosen by matched non-offenders than by sex offenders. The woman sexbot was considered more attractive by matched non-offenders than by sex offenders. The man sexbot was almost twice as likely to be found attractive by matched non-offenders than by sex offenders. The boy sexbot was considered more attractive by matched nonoffenders than by sex offenders (see Table 2 for comparative findings).

\subsubsection{Attitudes Towards Sexbots}

Contrary to expectations, when asked whether they would be interested in having a sexbot, only a few sex offenders manifested an interest in having a sexbot in comparison with non-offenders. Sex offenders almost completely dismissed any interest or curiosity in having an intimate and sexual relationship with a sexbot, in comparison with non-offenders who openly expressed their interest in, using their own words, «giving a sexbot a try».

Furthermore, findings suggest that sex offenders were less acceptant of sexbots, even when compared with the matched-control non-offenders. Sex offenders were less interested in having a sexbot in comparison with matchedcontrol non-offenders. The matched prosocial men were more significantly interested in having an intimate and sexual relationship with a sexbot in comparison with sex offenders (see Table 2). 
Table 2 Sex offenders versus non-offenders on openness and attitudes towards sexbots

\begin{tabular}{|c|c|c|c|}
\hline \multirow[t]{2}{*}{ Preferable sexbots } & \multicolumn{2}{|l|}{ Sample categories } & \multirow[t]{2}{*}{ Odds Ratios (95\% CI) } \\
\hline & Sex offenders (A) $n=100$ & Non-offenders (B) $n=244$ & \\
\hline Girl sexbot & $5.1 \%(n=5)$ & $26.2 \%(n=64)$ & \\
\hline Boy sexbot & $7.1 \%(n=7)$ & $7 \%(n=17)$ & \\
\hline Woman sexbot & $67.3 \%(n=66)$ & $57 \%(n=139)$ & \\
\hline Man sexbot & $7.1 \%(n=7)$ & $8.6 \%(n=21)$ & \\
\hline Variables on Sexbots & Sex offenders (A) $n=100$ & Non-offenders (B) $n=244$ & $\mathrm{~A} / \mathrm{B}$ \\
\hline Ever heard of sexbots & $50.0 \%(n=49)$ & $58.2 \%(n=142)$ & $.72(95 \% \mathrm{CI}=.45-1.15)$ \\
\hline Chosen: Girl sexbot & $24.0 \%(n=23)$ & $50.8 \%(n=124)$ & $.31(95 \% \mathrm{CI}=.18-.52) * * *$ \\
\hline Chosen: Boy sexbot & $25.5 \%(n=24)$ & $38.5 \%(n=94)$ & $.55(95 \% \mathrm{CI}=.32-.93)^{*}$ \\
\hline Chosen: Woman sexbot & $27.1 \%(n=26)$ & $31.6 \%(n=77)$ & $.81(95 \% \mathrm{CI}=.48-1.36)$ \\
\hline Chosen: Man sexbot & $26.9 \%(n=25)$ & $41.8 \%(n=102)$ & $.51(95 \% \mathrm{CI}=.30-.87)^{* *}$ \\
\hline Interest in having a sexbot & $12.4 \%(n=12)$ & $53.1 \%(n=129)$ & $.13(95 \% \mathrm{CI}=.07-.24) * * *$ \\
\hline $\begin{array}{l}\text { Having an intimate / sexual relationship with a } \\
\text { sexbot }\end{array}$ & $6.2 \%(n=6)$ & $36.6 \%(n=89)$ & $.14(95 \% \mathrm{CI}=.05-.27) * * *$ \\
\hline $\begin{array}{l}\text { Using a sexbot to treat sex offenders could reduce } \\
\text { violence against people }\end{array}$ & $24.7 \%(n=24)$ & $46.9 \%(n=105)$ & $.37(95 \% \mathrm{CI}=.22-.63) * * *$ \\
\hline $\begin{array}{l}\text { It would be more acceptable if sexual violence were } \\
\text { acted against a robot instead of a human being }\end{array}$ & $36.1 \%(n=35)$ & $51.6 \%(n=115)$ & $.53(95 \% \mathrm{CI}=.33-.87)^{* *}$ \\
\hline Variables on Sexbots & Sex offenders (A) $n=75$ & Matched-control (C) $n=75$ & $\mathrm{~A} / \mathrm{C}$ \\
\hline Ever heard of sexbots & $55.4 \%(n=41)$ & $42.7 \%(n=32)$ & $.60(95 \% \mathrm{CI}=.31-1.15)$ \\
\hline Chosen: Girl sexbot & $19.2 \%(n=14)$ & $50.7 \%(n=38)$ & $4.33(95 \% \mathrm{CI}=2.07-9.05)^{* * *}$ \\
\hline Chosen: Boy sexbot & $19.7 \%(n=14)$ & $41.3 \%(n=31)$ & $2.87(95 \% \mathrm{CI}=1.36-6.03)^{* *}$ \\
\hline Chosen: Woman sexbot & $23.3 \%(n=17)$ & $57.3 \%(n=43)$ & $4.43(95 \% \mathrm{CI}=2.18-9.00)^{* * *}$ \\
\hline Chosen: Man sexbot & $22.9 \%(n=16)$ & $38.7 \%(n=29)$ & $2.13(95 \% \mathrm{CI}=1.03-4.40)^{*}$ \\
\hline Interest in having a sexbot & $8.2 \%(n=6)$ & $70.7 \%(n=53)$ & $26.90(95 \% \mathrm{CI}=10.18-71.10)^{* * *}$ \\
\hline $\begin{array}{l}\text { Having an intimate / sexual relationship with a } \\
\text { sexbot }\end{array}$ & $6.8 \%(n=5)$ & $57.3 \%(n=43)$ & $18.28(95 \% \mathrm{CI}=6.61-50.53) * * *$ \\
\hline $\begin{array}{l}\text { Using a sexbot to treat sex offenders could reduce } \\
\text { violence against people }\end{array}$ & $23.3 \%(n=17)$ & $56.0 \%(n=42)$ & $4.19(95 \% \mathrm{CI}=2.06-8.52) * * *$ \\
\hline $\begin{array}{l}\text { It would be more acceptable if sexual violence were } \\
\text { acted against a robot instead of a human being }\end{array}$ & $32.9 \%(n=24)$ & $60.0 \%(n=45)$ & $3.01(95 \% \mathrm{CI}=1.56-6.00)^{* *}$ \\
\hline
\end{tabular}

Percentages exclude missing values. Column percentage are shown. $* p<.05 ; * * p<.01 ; * * * p<.001$

\subsection{Sexbots in the Prevention of Violence}

In line with the previous responses gathered in the study, sex offenders, in comparison with non-offenders, held a sceptical view about reducing the risk of violence by employing sexbots. Sex offenders were less likely than non-offenders to believe that the risk of sexual violence against people (men, women or children) could be reduced if a sexbot was used as a device in the treatment of sex offenders.

When asked whether it would be more acceptable if sexual violence were acted against a sexbot instead of a person, sex offenders were more reluctant to endorse this scenario in comparison with non-offenders, who instead saw this scenario as more socially acceptable given that in such a case «nobody would be hurt».
It is interesting to note that, when comparing 75 sex offenders with 75 matched controlled non-offenders, only some sex offenders expressed a favorable opinion of using sexbots in the treatment of sex offenders, while more than twice as many matched non-offenders supported this view. Moreover, the acceptance of sexually abusing a sexbot rather than a human being was nearly twice as high in matched non-offenders as in sex offenders. Table 2 shows these results.

\subsection{The Criminal Careers of Child Molesters and Rapists}

The criminal careers of the 100 sex offenders involved in the study were explored by looking at official data and the forensic files made available by the criminal justice system. 
Other studies have shown the importance of exploring sexoffending by also differentiating the criminal careers of the offenders [56].

$54.0 \%(n=54)$ child molesters and $46.0 \%(n=46)$ rapists were involved in this study. Table 3 shows the findings from this between-group comparison. Child molesters $(\underline{\mathrm{M}}=48.18$; $S D=13.82)$ were older than rapists $(\underline{\mathrm{M}}=42.59 ; S D=11.92)$, $t(98)=-2.144, p=0.017,(d=0.43)$. No difference was found in the level of social desirability between child molesters $(\underline{\mathrm{M}}=7.94 ; S D=3.01)$ and rapists $(\underline{\mathrm{M}}=8.05 ; S D=2.71)$, $t(96)=0.173, p=0.086,(d=0.03)$.

Sexual abuse duration refers to the persistence of abuse, either against different victims or against the same victim, and on independent occasions. Seventy-five sex offenders in the study were persistent. The duration of sexual offending, and sexual deviant continuity (measured in years) was slightly higher in child molesters $(\underline{\mathrm{M}}=3.71$; $S D=5.50)$ in comparison with rapists $(\underline{\mathrm{M}}=2.77 ; S D=5.34)$, $t(76)=-0.746, p=0.23,(d=0.17)$.

No difference was found between child molesters and rapists in static sexual risk measured with Static-99R and Static-2002R. Furthermore, no difference was found in the dynamic sexual risk, apart from sexual self-regulation which was significantly higher in child molesters $(\underline{\mathrm{M}}=1.26 ; \mathrm{SD}=1.19)$ than in rapists $(\underline{\mathrm{M}}=0.39 ; \mathrm{SD}=0.77)$, $t(98)=-4.254, p=0.0001(d=0.99)$ (see Table 3$)$.

In $22 \%$ of the cases, pornographic material was involved in the dynamic of violence: the use of explicit pedopornography and/or pornographic material ${ }^{4}$ was significantly correlated with sexual self-regulation difficulties $(r .=38$; 1-tailed test). The use of explicit sexual deviant material was significantly higher among child molesters $(37 \%$; $n=20)$ in comparison with rapists $(4.3 \% ; n=2), 12.94(95 \%$ $\mathrm{CI}=2.83-52.22$ ).

As expected, child molesters reported higher levels of cognitive distortions related to children, in comparison with rapists. Unexpectedly, child molesters also reported higher levels of cognitive distortions related to women, in comparison with rapists. It was less likely that child molesters $(n=12 ; 35.3 \%)$ were abusive against their partners, in comparison with rapists $(n=22 ; 64.7 \%),(\mathrm{OR}: 0.312 ; 95 \% \mathrm{CI}$ : 0.13-0.74) (see Table 3).

\subsection{Sexbots for Child Molesters and Rapists}

It was interesting to see that no significant differences were found between child molesters and rapists relating to sexbots. Only a small proportion of them seemed specifically interested in any child sexbots or adult sexbots,

\footnotetext{
${ }^{4}$ No information about the use of pornographic material was gathered for non-offenders.
}

and a small number of them looked at sexbots as a possible device to employ in the treatment of sex offenders to reduce the risk of violence (see Table 3 for details about these results). However, those child molesters $(n=7 ; 63.6 \%)$ who reported a higher level of emotional identification with children (EIWC), measured with the Stable-2007, compared to child molesters with a lower EIWC ( $n=13 ; 30.2 \%)$, were twice as inclined to see violence against a sexbot, rather than against a human being, as more acceptable (OR: 4.04; $95 \%$ $\mathrm{CI}=1.01-16.22)$.

\section{Discussion}

Currently very few studies that explored the views people had about the use of sexbots and of their acceptability of having an intimate relationship with a sexbot, are available $[13,74]$.

Two empirical questions were at the basis of this study. The first revolved around the idea of a relationship with a robot that implies affection, sexuality and emotional investment. The second concerned the possibility of using sexbots to treat sex offenders.

Moreover, working with sex offenders, we are advocating that the possibility of employing sexbots in the treatment and rehabilitation of sex offenders must be explored, and a scientific debate must be encouraged. The interest of this study was also to speculate on an important practical question of whether consumers of sexbots pose a risk for hands-on sex offenses. This is why this study can be a stepping-stone to enhance our understanding on the use of sexbots with sex offenders, and promote more research.

This study carried out two types of comparisons. Male sex offenders were compared with male non-offenders, and more specifically 75 sex offenders were compared with a subsample of 75 matched non-offenders. Moreover, the sex offenders were divided into two subgroups depending on their criminal careers: child molesters and rapists.

The preliminary findings of this study suggest that sexbots have already entered the physical and imaginary world of human beings: most of the participants in this study admitted to have heard of and seen sexbots, especially via social media.

\subsection{Being in a Relationship with a Sexbot: a Comparison Between Sex Offenders and Non-Offenders}

Notwithstanding that previous studies suggest that those who are quite open in admitting their interest in having a relationship with a sexbot were not necessarily problematic in terms of psycho-sexual functioning and life satisfaction [117], some anecdotal evidence seems to indicate otherwise. 
Table 3 Criminal careers, level of sexual risk, openness and attitudes towards sexbots of child molesters and rapists

\begin{tabular}{|c|c|c|c|c|}
\hline \multirow{3}{*}{$\begin{array}{l}\text { Criminal careers } \\
\text { Types of offenders }\end{array}$} & \multicolumn{4}{|l|}{ Sample categories } \\
\hline & \multicolumn{2}{|l|}{ Child molesters $n=54$} & \multicolumn{2}{|l|}{ Rapists $n=46$} \\
\hline & $n$ & $\%$ & $n$ & $\%$ \\
\hline Heterogeneous & 17 & 70.0 & 26 & 56.5 \\
\hline Specialized & 7 & 13.0 & - & - \\
\hline Persistent & 24 & 44.4 & 25 & 54.3 \\
\hline One-timer & 30 & 55.6 & 21 & 45.7 \\
\hline Deviant sexual continuity & 46 & 85.2 & 32 & 69.6 \\
\hline Involved in Intimate Partner Violence & 12 & 22.2 & 22 & 47.8 \\
\hline \multicolumn{5}{|c|}{ Victims (of Child molesters: $n=176$; of Rapists: $n=80$ ) } \\
\hline Intrafamily & 25 & 46.3 & 17 & 37.0 \\
\hline Incest & 13 & 24.1 & 1 & 2.2 \\
\hline Known & 41 & 75.9 & 28 & 60.9 \\
\hline Stranger & 13 & 24.1 & 18 & 39.1 \\
\hline Male & 14 & 25.9 & - & - \\
\hline Female & 40 & 74.1 & 46 & 100 \\
\hline Hand-off sex-offense & 19 & 35.2 & 3 & 6.5 \\
\hline Hand-on sex-offense & 35 & 64.8 & 43 & 93.5 \\
\hline Level of sexual risk & Child molesters $n=54 \mathrm{M}(S D)$ & Rapists $n=46 \mathrm{M}(S D)$ & $t$-test $(d f)$ & Cohen's $d$ \\
\hline Static risk (measured with Static-99R) & $1.30(2.79)$ & $1.72(2.66)$ & $t(98)=.769, p=.22$ & 0.15 \\
\hline Static risk (measured with Static-2002R) & $2.89(2.96)$ & $2.83(2.33)$ & $t(98)=-.116, p=.47$ & 0.02 \\
\hline $\begin{array}{l}\text { Dynamic risk (measured with Sta- } \\
\text { ble-2007) }\end{array}$ & $9.09(4.01)$ & $8.35(4.38)$ & $t(98)=-.878, p=.19$ & 0.18 \\
\hline Intimacy deficit & $4.39(2.29)$ & $4.02(1.99)$ & $t(98)=-.847, p=.19$ & 0.17 \\
\hline Sexual self-regulation & $1.26(1.19)$ & $.39(.77)$ & $t(98)=-4.254, p=.0001 * * *$ & 0.99 \\
\hline Significant social influence & $1.04(.64)$ & $1.04(.63)$ & $t(98)=.050, p=.48$ & 0.0 \\
\hline General self-regulation & $1.85(1.24)$ & $2.13(1.47)$ & $t(98)=1.030, p=.15$ & 0.21 \\
\hline Cooperation with supervision & $.56(.66)$ & $.76(.64)$ & $t(98)=1.569, p=.60$ & 0.31 \\
\hline \multicolumn{5}{|l|}{ Cognitive distortions } \\
\hline $\begin{array}{l}\text { Cognitive distortions towards children } \\
\text { (Bumby Molest) }\end{array}$ & $52.95(15.07)$ & $45.53(7.81)$ & $t(66)=-2.446, p=.01$ & 0.62 \\
\hline $\begin{array}{l}\text { Cognitive distortions towards women } \\
\text { (Bumby Rape) }\end{array}$ & $60.43(14.97)$ & $52.73(15.34)$ & $t(68)=-2.105, p=.02$ & 0.51 \\
\hline Social desirability & $7.94(3.01)$ & $8.05(2.71)$ & $t(96)=.173, p=.43$ & 0.03 \\
\hline Variables on Sexbots & Child molesters $n=54$ & Rapists $n=46$ & Odds Ratios (95\% CI) & \\
\hline Ever heard of sexbots & $53.7 \%(n=29)$ & $45.5 \%(n=20)$ & $1.39(95 \% \mathrm{CI}=.63-3.10)$ & \\
\hline Chosen: Girl sexbot & $25.9 \%(n=14)$ & $21.4 \%(n=9)$ & $1.28(95 \% \mathrm{CI}=.49-3.34)$ & \\
\hline Chosen: Boy sexbot & $23.1 \%(n=12)$ & $28.6 \%(n=12)$ & $.75(95 \% \mathrm{CI}=.30-1.90)$ & \\
\hline Chosen: Woman sexbot & $27.8 \%(n=15)$ & $26.2 \%(n=11)$ & $1.08(95 \% \mathrm{CI}=.44-2.69)$ & \\
\hline Chosen: Man sexbot & $26.9 \%(n=14)$ & $26.8 \%(n=11)$ & $1.01(95 \% \mathrm{CI}=-.40-2.53)$ & \\
\hline Interest in having a sexbot & $11.1 \%(n=6)$ & $14.0 \%(n=6)$ & $.77(95 \% \mathrm{CI}=.23-2.59)$ & \\
\hline $\begin{array}{l}\text { Having an intimate / sexual relationship } \\
\text { with a sexbot }\end{array}$ & $9.3 \%(n=5)$ & $2.3 \%(n=1)$ & $4.29(95 \% \mathrm{CI}=.48-38.15)$ & \\
\hline $\begin{array}{l}\text { Using a sexbot to treat sex offenders } \\
\text { could reduce violence against people }\end{array}$ & $25.9 \%(n=14)$ & $23.3 \%(n=10)$ & $1.16(95 \% \mathrm{CI}=.45-2.94)$ & \\
\hline $\begin{array}{l}\text { It would be more acceptable if sexual } \\
\text { violence were acted against a robot } \\
\text { instead of a human being }\end{array}$ & $37.0 \%(n=30)$ & $34.9 \%(n=15)$ & $1.10(95 \% \mathrm{CI}=.48-2.53)$ & \\
\hline $\begin{array}{l}\text { Use of pedopornographic and/or porno- } \\
\text { graphic material }\end{array}$ & $37.0 \%(n=20)$ & $4.3 \%(n=2)$ & $12.94(95 \% \mathrm{CI}=2.83-52.22) * * *$ & \\
\hline
\end{tabular}

${ }^{*} p<.05 ; * * p<.01 ; * * * p<.001$ 
In this study, sex offenders were more reluctant to speak about their preferences towards sexbots. While male nonoffenders appeared to be open to sexbots and quite eager to imagine themselves having a relationship with a sexbot or having sexual intercourse with one of them, sex offenders were reluctant to admit any interest towards sexbots. No clinical data are available to support the assumption about whether the interaction with sexbots is in any way egodystonic (inconsistent with one's ideal self) or egosyntonic (consistent with one's ideal self). Thus, no-one can discount the influence of being in detention upon the offenders' willingness to feel at ease in expressing their views. It is not unusual that, when in detention, offenders may put up a front. This might explain why the sex offenders in this study kept a low profile on sex matters (e.g. declaring that "sexbots are not for me, I'm not a pervert", to use their words). Sexuality is a dirty word for sex offenders in detention and their willingness to be seen as reformed and «sexually normal» is what perhaps motivated them to deny that they had any form of curiosity or attraction for any sexbot presented to them.

\subsection{The Influence of Criminal Careers Upon Acceptancy of Sexbots}

These results suggest further ways of looking at the dynamic risk posed by these sex offenders. A high percentage of them had a high level of dynamic risk, as measured with Stable-2007 (see Table 3). The dimension that was significantly impaired was sexual self-regulation, which is a relevant criminogenic need that directly influences behavior and exacerbates the risk of recidivism.

This reluctance to exhibit any form of curiosity or interest towards any sexbot was also strong in those sex offenders for whom the use of pedopornography and deviant images was central in the dynamics of their crimes. The use of pornography and/or pedopornography among them did not seem to have made them any less at risk. Making a lap in comparative thinking between pornography and sexbots, it can perhaps be assumed that their use of this material might not promote enough sexual arousal and satisfy their sexual fantasies. More evidence would be necessary, however, to support this assumption.

However, this possibility does not deny that some sex offenders, if not all, were truly disinterested in sexbots. In line with other studies [10], the idea of "the more humanlike the better" might have made our sex offenders less inclined to accept sexbots as potential partners or potential therapeutic devices. Increased realism in making sexbots more humanlike does not necessarily guarantee more acceptance [9]. As mentioned earlier, the concept of the uncanny valley [7] states that, as any non-human entity is made more humanlike in its appearance, the emotional response to it is positive until a ceiling-point is reached at which repulsion becomes the frequent response [10].

While there is no doubt that the uncanny valley effect is not exclusively applicable to sex offenders, as evidence points out, it might have, paradoxically, a more intense effect upon those who are more sexually deviant. The sex offenders involved in this study were responsible for the most extreme sexual acts against children and adult victims, and for some of them the level of sexual deviance was significantly high. This might have made them more susceptible to the idea of being in need of more than a sexbot to satisfy their sexual self. It may also be that sex offenders know better than prosocial men what it means to sexually abuse a person-either an adult or a child - and what are the motivations behind those acts. If at a scientific and clinical level they are not qualified to assess their criminogenic needs, at a psychological level they are people who have experienced the effect of sexual deviance and sexual self-regulation difficulties on their life.

Some other explanations might be plausible.

From a socially redemption perspective, what might have influenced the responses of sex offenders in this study is their motivation not only to encounter the approval of those professionals responsible for their risk assessment but especially to regain trust from their family members or their exor potential partners. It is significant to mention that $63 \%$ of them $(n=63)$ were single or separated at the time their study took place, in comparison with $71 \%$ of them $(n=71)$ who were in a relationship at the time of the crime. Certainly, more research is needed to explore the possible selves of sex offenders, not only within the controlled setting of detention, but also beyond that, in their real psychosocial world.

Rothstein and colleagues [118] explored the extent to which individuals perceive infidelity when cheating their partners with a sexbot. Respondents rated their interactions with sexbots as being less disrespectful and less likely to be judged as infidelity as those same acts committed with another human. However, when asked to focus specifically on a relationship with a sexbot, with biological features that were matched sex-wise to their own partners, some interesting results followed. When the sex of the robot was made salient and consistent with the sex of their own partner, the interaction with the sexbot was perceived as a real form of infidelity.

In line with these findings, if the idea of interacting with a highly biologically defined sexbot can be seen as cheating one's own partner, it is possible that for the sex offenders in this study, a way of redeeming themselves in the eyes of their families and partners was to reject any alternative relationships including even those in the form of surrogacy. Any of these relationships were perhaps to be perceived as unfair towards their partners and as reifying some sort of connection with their sexually deviant past. 
On the other hand, it might be that the sexbots presented were in fact not particularly appealing to the participants in the study or did not induce much imaginative thought or sexual arousal. This may be why their level of acceptancy of them was quite low.

Providing participants with static images of sexbots may have fostered the idea of them not being intentional agents, hence inhibiting the activation of brain circuits subserving social cognition [119]. On the contrary, in our experiment, seeing sexbots as only artefacts might have failed to evoke typical human-human exchange mechanisms such as mentalization and empathy.

\subsection{Fostering Sociality with Sexbots}

For the 'fostering sociality' hypothesis, presented before, it may be possible that sexbots can ultimately play, for certain individuals, a significant role in alleviating some psychological burdens, such as loneliness, self-inadequacy, insecurity or boredom. The sex doll-owners involved in Valverde's review [117] described the sexual experiences with their dolls as enjoyable, and $40 \%$ of them owned more than one doll. Moreover, while a considerable number of doll-owners were in a relationship with a human partner and/or had more than one doll, some respondents declared that they turned to dolls after losing their spouse or partner, as a doll was a therapeutic transitional object to cope with grief. They did not show any particular mental problem and no clinical study has warranted that doll or sexbot ownership is a necessary and sufficient criterion for a diagnosis of paraphilia. However, post-hoc results showed that rates of self-reported depression among respondents were slightly higher than the national male averages for lifetime prevalence of major depression [120], though not significantly so. Moreover, it emerged that the rate of depression among those participants who did not have a sex doll, but would like to have one, was significantly higher than among doll-owners.

\subsection{Limiting Harm with Sexbots}

According to the 'harm limitation' hypothesis (see the description reported earlier in the article), to the extent that the prevention of sexual violence is paramount, every possible avenue ought to be scientifically explored. This might be encouraged by the progress made by social robotics when assessing the improved quality of life of some people (e.g. disabled people or older adults with disabilities) in interacting with robots, which are perceived not as «just hardware machines» but more as «social entities» [74]. Improving the wellbeing of people, helping people carry out their life in autonomy, is in fact one aim of social robotics.

The possibility that a sexbot may help to shift sexually deviant interests from children or women to sexbots does not warrant the certainty that the sex offender would not relapse into crime. This point however applies to any type of treatment: the efficacy of any treatment varies and depends on many factors, and not only on the quality of the instruments or protocols employed [121]. The scientific basis of a treatment does not necessarily guarantee positive results, nor is the efficacy of a treatment a guarantee of a long-term duration of the effects [122].

Some people would even perceive child sexbots as a way of reinforcing a perversion. Some others would instead consider a child sexbot not only a recreational tool, but as a therapeutic device that could protect children and society [123, 124].

Before any treatment is designed, it is necessary to recognize individual differences underlying criminal careers, and the variety of psychological attitudes towards sexuality. Child sexbots could function as an alternative means of treatment for child molesters and pedophiles [18]. It is important to make clear that not every child molester is a pedophile, and that sex offenders are not all alike. It might in fact be that the efficacy of sexbots in dealing with deviant sexual fantasy is stronger with pedophiles rather than with sex offenders who are involved in a heterogeneous criminal career. Studying men who possess a child sexbot may expand our understanding of sexual deviance in prosocial individuals who are less psychologically impaired than those who are assessed in clinical settings [125, 126].

Risk dimensions such as sexual self-regulation constitute significant motivations for committing sex offences, while antisociality facilitates acting upon those motivations. Both dimensions predict sexual recidivism [127], with antisociality predicting also general recidivism [128].

\subsection{Scientific Responsibility for Future Sexbots Research}

The futuristic thinking that seems to dissolve the distinction between humans and machines [102] suggests further reflections on whether sexbots could become substitute sexual objects to shift the interest of sex offenders from humans to machines. Notwithstanding that such a scenario is highly speculative, psychologists have some scientific responsibility for carrying out further research on how sexbots shape behavior and influence interpersonal relationships in different circumstances and with different people. No one can discount that robots have become important devices to help humans organize daily routines, to surrogate them in some rehabilitative work in homecare facilities, healthcare centers, schools, and industries, and to become companions to talk to and interact with. According to the social surrogacy hypothesis [129], social and rehabilitative needs can be satisfied by robots, which are seen as virtual entities that can buffer against social exclusion and rejection via «parasocial 
relationships», by providing the experience of belonging. With regard to this, some scholars propose a unifying discipline (defined as erobotics), combining human-machine interaction and sexology to study how human beings and machines evolve together to address the development of machines with the aim of supporting socio-sexual wellbeing [130].

Proposals for how sexbots for pedophilic use could be regulated should be always sustained and informed by scientific evidence, and we are far from imagining that sexbots should be made available indiscriminately. Like the introduction of virtual reality in clinical settings [131] and in the criminal justice system [132], the use of sexbots should certainly be authorized by psychological and mental health professionals, under scientific supervision, and approved by ethics committees.

One of the messages to take home from this study is that any intervention and rehabilitation of sex offenders starts from taking into consideration how sex offenders present themselves socially, and to what extent they may be aware of and admit their sexual deviance, when present, and the criminogenic needs that motivated their sexual violence. Sexuality is the most secretive part of a person's life and this seems to apply more so to sex offenders [49].

There is no doubt that the present findings are only preliminary. They call for more research on the psychologically adaptive and maladaptive uses of sexbots, and on the paradoxical impact of sexual deviance (e.g. sexual self-regulation) on lowering the acceptance of sexbots.

Scientists should be aware that technology is moving fast and that a preference for synthetic relationships could become mainstream social behavior and might no longer be considered deviant, unusual, problematic or pathological [133]. This may also change the way sex offenders look at or imagine their relationships with sexbots, and start to see them as social entities with whom they can redeem their habits, and readjust their behavior.

At least one question still calls for some answers: what does the use of sexbots in the treatment of sex offenders involve? Though speculative, no one could dismiss the possibility that the use of sexbots in the treatment of sex offenders might have similar effects to the ones elicited by virtual reality, or viewing time, or virtual pornography. Research has demonstrated the potential of these techniques in the diagnosis, risk-assessment and treatment of sexual deviance, especially for child molesters [134]. The advent of sexbots might encourage their use in an immersive visual stimuli scenario for inducing sexual arousal, and assessing it with penis plethysmography (PPG) [135]. Some experts also assume that by simulating virtual sexual arousing scenarios, it is possible to test which situations create a high risk condition for sexually problematic individuals, and to monitor which responses they are likely to give in the presence of specific stimuli. The application of virtual technologies, that also employ sexbots, may have important advantages for prevention too, in so far as it bears the possibility of monitoring, controlling, and re-directing the sexual behavior of high-risk child molesters in less risky and under-controlled situations, without endangering real children.

\subsection{Limitations of the Study}

This study is not without limitations. First, the sample involved only male sex offenders, which directed the choice of involving only non-offender males. Studying the perceptions that women hold about sexbots and their sexuality would be particularly insightful to understand changes and differences in how sexuality is perceived, presented, experienced and narrated in Western society, and how cognitive distortions might populate the female psychological world.

The sample in this study was composed mostly of Italian men; how these results can be generalized to men from other nationalities is difficult to say. However, some of the cautions that most participants, in this study, showed towards sexbots and their acceptancy were similar to the reactions gathered from other research [136], suggesting that these findings might be reasonably applicable to the Western world [137]. It would be interesting to carry out a multicultural comparison in order to be able to identify the impact of culture in liberalizing views on sexbots.

It would have been interesting to explore personality traits and how they relate to the openness or resistance towards sexbots as showed by the respondents in this study. Already, Turkle and colleagues [2] suggested that differences in individual responses to technology can be a window into personality, life history, and cognitive style.

More studies are necessary to analyse how personality affects the individual's openness and responses to technology.

The interpretation of these findings should also take into account methodological limitations. This study faced tremendous challenges and bureaucratic impediments that affected the sample size and the access to risk-assessment. As Zara and colleagues [56] already stated, examining risk levels among sexual offenders in Italy is problematic because of the lack of available data, which are readily accessible in other countries' departments of justice and corrections [138].

Moreover, the experimental material i.e. the images of sexbots used in the study might, to a certain extent, have influenced the responses of the participants, not least because they displayed only the faces of the sexbots and perhaps making it difficult to appreciate their likeability. Notwithstanding that faces are important in attracting attention and enhancing interaction, the use of only sexbots' faces might have not triggered the interest of, 
especially, the sex offenders involved in the study. Perhaps some more explicit images of body and sexual features of the sexbots could have elicited different reactions, and this needs to be further explored in future studies in which full body images of sexbots are employed. However, researchers should also take into account two aspects related to such studies. The first regards the importance of not generating some uncooperative or resistant reactions by sex offenders who have proved to be a quite diffident and defensive treatable population [139]. The second is concerned with the ethical issues that might arise when showing explicit or more evocative photos to sex offenders in detention.

Despite these limitations, this is the first Italian study that has attempted to examine the perceptions of sexbots as sexual partners and as a means to prevent sexual violence against victims. Looking at sexbots in diverse social contexts (e.g. detention and prosocial world) has contributed to a better appreciation of the social complexity behind the relationship of human beings with their sexuality.

These findings are also relevant because they offered some first-hand information about reactions towards sexbots. The disinterest of sex offenders towards sexbots might occur as a sort of resistance towards treatment in general, and towards the use of sexual mechanical devices in particular. It might also be an expression of a truthful lack of attraction to sexbots per se. Whatever the reasons, professionals involved in the treatment of sex offenders should contemplate these aspects. Resistance to treatment should not be polarized but rather addressed before starting any type of treatment with or without any mechanical device (e.g. sexbots). If future research evidence supports the inclusion of sexbots into a treatment protocol, experts should be encouraged to take into account also the possible lack of arousal towards sexbots that might affect the assessment of sexual deviance and risk, and their impact on adherence to treatment.

Even if no definitive conclusion can be drawn, how sex offenders differ in their dynamic risk and criminal careers can inform experts about the mechanisms that underlie behavior and can challenge the engagement in treatment and intervention. Hence this study also contributes to the literature because it challenges some scientifically unsupported views that sex offenders are a homogeneous group of offenders [101], and are more openly disinhibited about sexuality than the general population [56].

Acknowledgements The authors are grateful to the anonymous Reviewers for their insightful and critical comments on a previous version of this work.

Funding Open access funding provided by Università degli Studi di Torino within the CRUI-CARE Agreement. No funding was received to carry out this study.
Data Availability Upon request.

\section{Declarations}

Conflict of interest The authors declare they have no conflict of interest.

Consent to Participate Participants signed the informed consent form whose statement is as follows: "I acknowledge that the procedures of the study has been explained to me. I have understood that I can withdraw from the study at any time without consequence. I have been informed that the contents of the interviews and the exchanges during the assessment tasks are completely confidential and that under no circumstances what I have disclosed within the research would be made public or used to inform the criminal justice system. I, therefore, consent to participate in the study and consent for the researchers to use the anonymized material for scientific purposes".

Ethical Approval The authors declare that the present study comply with the current Italian laws and with the ethics principles for research in psychology. The study has been approved by the Bioethic Committee of the University of Turin (Italy) (protocol reference number 6494/2018). The research protocol was organized according to The Italian Data Protection Authority Act nr. 9/2016, art. 1 and 2 (application and scientific research purposes), and to the recent General Data Protection Regulation (GDPR, 2018), and it was carried out in line with the Italian and the EU code of human research ethics and conduct in psychology.

Open Access This article is licensed under a Creative Commons Attribution 4.0 International License, which permits use, sharing, adaptation, distribution and reproduction in any medium or format, as long as you give appropriate credit to the original author(s) and the source, provide a link to the Creative Commons licence, and indicate if changes were made. The images or other third party material in this article are included in the article's Creative Commons licence, unless indicated otherwise in a credit line to the material. If material is not included in the article's Creative Commons licence and your intended use is not permitted by statutory regulation or exceeds the permitted use, you will need to obtain permission directly from the copyright holder. To view a copy of this licence, visit http://creativecommons.org/licenses/by/4.0/.

\section{References}

1. Johnson DJ, Verdicchio M (2019) AI, agency and responsibility: the VW fraud case and beyond. AI \& Soc 34:639-647. https:// doi.org/10.1007/s00146-017-0781-9

2. Turkle S, Taggar W, Kidd CD, Dasté O (2006) Relational artifacts with children and elders: the complexities of cybercompanionship. Connect Sci 18:347-361. https://doi.org/10.1080/09540 090600868912

3. Cox-George C, Bewley S (2018) I, Sex robot: the health implications of the sex robot industry. BMJ Sex Reprod Health 44:161164. https://doi.org/10.1136/bmjsrh-2017-200012

4. Turkle S (2005) The second self: computers and the human spirit. MIT Press, Cambridge MA

5. Fosch-Villaronga E, Poulsen A (2020) Sex care robots. Exploring the potential use of sexual robot technologies for disabled and elder care. Paladin J Behav Robot 11:1-18. https://doi.org/10. 1515/pjbr-2020-0001 
6. Gersen JS (2019) Sex lex machina: intimacy and artificial intelligence. Colum L Rev 119:1793-1809

7. Mori M (1970) The uncanny valley. Energy 7:33-35

8. MacDorman KF, Green RD, Ho CC, Koch CT (2009) Too real for comfort? Uncanny responses to computer generated faces. Comput Hum Behav 25:695-710

9. Pollick FE (2010) In Search of the Uncanny Valley. In: Daras P, Ibarra OM (ed) User Centric Media. UCMEDIA 2009. Lecture Notes of the Institute for Computer Sciences Social Informatics and Telecommunications Engineering (vol. 40). Berlin and Heidelberg, Germany, Springer, pp 69-78. https://doi.org/10.1007/ 978-3-642-12630-7_8

10. Arras KO, Cerqui D (2005) Do we want to share our lives and bodies with robots? A 2000 people survey. Technical report Nr. 0605-001 Autonomous systems lab Swiss Federal Institute of Technology, EPFL

11. Haring KS, Waranabe K, Mougenot C (2013) The influence of robot. HRI '13: Proceedings of the 8th ACM/IEEE international conference on Human-robot interaction, 131-132

12. Zanatto D, Patacchiola M, Cangelosi A, Goslin J (2020) Generalisation of anthropomorphic stereotype. Int J Soc Robot 12:163172. https://doi.org/10.1007/s12369-019-00549-4

13. Döring N, Mohseni MR, Walter R (2020) Design, use, and effects of sex dolls and sex robots: scoping review. J Med Internet Res 22:e18551. https://doi.org/10.2196/18551

14. Scheutz M, Arnold T (2016) "Are we ready for sex robots?", in the $11^{\text {th }}$ annual ACM/IEEE international conference on humanrobot interaction [HRI], Christchurch, 351-358

15. Yulianto B, Shidarta S (2015) Philosophy of information technology: sex robot and its ethical issues. Int J Soc Ecol Sustain Dev 6:67-76. https://doi.org/10.4018/IJSESD.2015100105

16. Edirisinghe C, Cheok AD, Khougali N (2017) Perceptions and responsiveness to intimacy with robots: a user evaluation. International conference of Love and Sex with Robots. Springer, Cham, pp 138-157. https://doi.org/10.1007/978-3-319-763699 11

17. Szczuka J, Krämer NC (2017) Not only the lonely - How men explicitly and implicitly evaluate the attractiveness of sex robots in comparison to the attractiveness of women, and personal characteristics influencing this evaluation. Multimodal Technol Interact 1:1-18. https://doi.org/10.3390/mti1010003

18. Behrendt M (2018) Reflections on moral challenges posed by a therapeutic childlike sexbot. In: Cheok AD, Levy D (eds) Love and sex with robots. Third international conference, LSR 2017 London UK, December 19-20, 2017 revised selected papers. Springer International Publishing AG, part of Springer Nature, Cham Switzerland, pp 96-113. http://doi-org-443.webvpn.fjmu. edu.cn/https://doi.org/10.1007/978-3-319-76369-9_8

19. Chatterjee BB (2019) Child sex dolls and robots: challenging the boundaries of the child protection framework. Int Rev Law, Comput Technol 34:22-43. https://doi.org/10.1080/13600869. 2019.1600870

20. Danaher J (2014) Robotic rape and robotic child sexual abuse: Should they be criminalised? Crim Law Philos 11:71-95. https:// doi.org/10.1007/s11572-014-9362-x

21. Maras MH, Shapiro LR (2017) Child sex dolls and robots: more than just an uncanny valley. J Internet Law 21:3-21

22. Strikwerda L (2017) Legal and moral implications of child sex robots. In: Danaher J, McArthur N (eds) Robot sex: social and ethical implications. MIT Press, Cambridge MA, pp 8-24

23. Danaher J (2019) Regulating child sex robots: restriction or experimentation? Med Law Rev 27:553-575. https://doi.org/10. 1093/medlaw/fwz002

24. Broadbent E, Kumar V, Li X, Sollers J, Stafford RQ, MacDonald BA, Wegner DM (2013) Robots with display screens: a robot with a more humanlike face display is perceived to have more mind and a better personality. PLoS ONE 8:e72589

25. Giger JC, Piçarra N, Alves-Oliveira P, Oliveira R, Arriaga P (2019) Humanization of robots: Is it really such a good idea? Hum Behav Emerg Technol 1:111-123. https://doi.org/10.1002/ hbe2.147

26. Turner J (2019) Robot rules. Regulation artificial intelligence. Palgrave Macmillan, London

27. Balistreri M (2018) Sex robot: l'amore al tempo delle macchine [Sex robots: love at the time of machines]. Fandango, Roma

28. Nordmo M, Naess JO, Husoy MF, Arnestad MN (2020) Friends, lovers or nothing: men and women differ in their perceptions of sex robots and platonic love robots. Front Psychol 11:1-10. https://doi.org/10.3389/fpsyg.2020.00355

29. Hoorn JF (2018) From lonely to resilient through humanoid robots: building a new framework of resilience. J Robotics 2018:1-17. https://doi.org/10.1155/2018/8232487

30. Facchin F, Barbara G, Cigoli V (2017) Sex robots: the irreplaceable value of humanity. BMJ 358:3790

31. Torjesen I (2017) Sixty seconds on... sex with robots. BMJ. https://doi.org/10.1136/bmj.j3353

32. Moen OM, Sterri AB (2018) Pedophilia and computer-generated child pornography. In: Boonin D (ed) The Palgrave handbook of philosophy and public policy. Palgrave Macmillan, Cham. https://doi.org/10.1007/978-3-319-93907-0_29

33. Morgan R (1980) Theory and practice: pornography and rape. In: Lederer L (ed) Take back the night: women on pornography. William Morrow \& Co., New York, pp 134-140

34. Langcaster-James M, Bentley GR (2018) Beyond the sex doll: post-human companionship and the rise of the 'Allodoll.' Robotics 7:1-20. https://doi.org/10.3390/robotics7040062

35. Goldstein JD (2017) Was It good for you too? The natural law tradition and the paradoxical good of sexbots. In: Danaher J, McArthur N (eds) Robot sex: social and ethical implications. The MIT Press, Cambridge MA, pp 173-200

36. Nyholm S (2015) Love troubles: human attachment and biomedical enhancements. J Appl Philos 32:190-202. https://doi. org/10.1111/japp.12085

37. Nyholm S, Frank LE (2017) From sex robots to love robots: Is mutual love with a robot possible? In: Danaher J, McArthur N (eds) Robot sex: social and ethical implications. The MIT Press, Cambridge MA, pp 219-245

38. McWhirter BT (1990) Loneliness: a review of current literature, with implications for counseling and research. J Couns Dev 68:417-422

39. Eggleton J (2018) Comment on 'I, sex robot: the health implications of the sex robot industry.' BMJ Sex Reprod Health 45:78-79. https://doi.org/10.1136/bmjsrh-2017-200012

40. Cheok AD, Devlin K, Levy D (2017) Love and sex with robots. Second international conference, LSR 2016, London UK, December, 19-20, 2016, Revised selected papers

41. Rutkin A (2016) Curbing dark desires. New Sci 231:20. https:// doi.org/10.1016/S0262-4079(16)31459-2

42. Birnbaum GE, Kanat-Maymon Y, Mizrahi M, Recanati M, Orr R (2018) What fantasies can do to your relationship: The effects of sexual fantasies on couple interactions. Pers Soc Psychol Bull 45:461-476

43. Ziegler A, Conley T (2016) The importance and meaning of sexual fantasies in intimate relationships. In: Aumer KV (ed) The Psychology of Love and Hate in Intimate relationship. Springer, New York, pp 29-45

44. Rutkin A (2017) Could sex robots and virtual reality treat paedophilia? New Scient [online]. https://www.newscientist. com/article/2099607-could-sex-robots-and-virtual-realitytre at-paedophilia/ (accessed 25 Aug 2017) 
45. Bader M (2003) Arousal. Virgins Books, London, The secret logic of sexual fantasies

46. Schlesinger LB (2000) Serial homicide: sadism, fantasy, and a compulsion to kill. In: Schlesinger LB (ed) Serial offenders: current thought. Recent Findings, CRC Press, New York, pp 3-22

47. Carabellese F, Candelli C, La Tegola D, Catanesi R (2010) Fantasie sessuali, disturbi organici, violenze sessuali. Rassegna Ital di Criminol 2:347-360

48. Beres D (1960) Perception, imagination, and reality. Int J Psychoanal 4:328

49. Zara G (2018b) Il diniego nei sex offender: dalla valutazione al trattamento [Denial in sex offenders: from assessment to treatment]. Raffaello Cortina, Milano

50. Porter R, Hall L (1995) The Facts of life: the creation of sexual knowledge in Britain, 1650-1950. Yale University Press, New Haven

51. Birnbaum GE, Mikulincer M, Gillath O (2011) In and out of a daydream: attachment orientations, daily couple interactions, and sexual fantasies. Pers Soc Psychol Bull 37:1398-1410

52. Howitt D (2004) What Is the role of fantasy in sex offending? Crim Behav and Ment Health 14:182-188

53. Zara G (2018a) La psicologia dei sexbot nel trattamento dei sex offender [The psychology of sexbots in the treatment of sex offenders]. In: Balistreri M (2018) Sex robot: l'amore al tempo delle macchine [Sex robots: love at the time of machines]. Fandango, Roma, pp 225-282

54. Nunes KL, Pettersen C, Hermann CA, Looman J, Spape J (2016) Does change on the MOLEST and RAPE scales predict sexual recidivism? Sex Abuse A J Res Treat 28:427-447

55. Montgomery KA (2008) Sexual desire disorders. Psychiatry 5:50-55

56. Zara G, Farrington DP, Jung S (2020) Denial in sex offending treatment: examining criminal career diversity. J Foren Psychol Res Prac 20:451-473. https://doi.org/10.1080/24732850.2020. 1776050

57. Sheldon K, Howitt D (2008) Sexual fantasy in paedophile offenders: Can any model explain satisfactorily new findings from a study of internet and contact sexual offenders? Leg Criminol Psychol 13:137-158

58. Greenberg JS, Bruess CE, Oswalt SB (2013) Exploring the dimensions of human sexuality. Jones \& Bartlett Learning, Burlington MA

59. Riegel DL (2004) Effects on boy-attracted pedosexual males of viewing boy erotica. Arch Sex Behav 33:321-323. https:// doi.org/10.1023/B:ASEB.0000029071.89455.53

60. Diamond M, Jozifkova E, Weiss P (2009) Pornography and sex crimes in the Czech Republic. Arch Sex Behav 40:1037-1043. https://doi.org/10.1007/s10508-010-9696-y

61. Kutchinsky B (1991) Pornography and rape: Theory and practice? Evidence from crime data in four countries where pornography is easily available. Int J Law Psychiatry 14:47-64

62. Kutchinsky B (1973) The effect of easy availability of pornography on the incidence of sex crimes: the Danish experience. J Soc Issues 29:163-181

63. Bridges AJ, Wosnitzer R, Scharrer E, Sun C, Liberman R (2010) Aggression and sexual behavior in best-selling pornography videos: a content analysis update. Viol Against Women 16:1065-1085. https://doi.org/10.1177/1077801210382866

64. Burt MR (1980) Cultural myths and supports for rape. J Pers Soc Psychol 38:217-230

65. Lonsway KA, Fitzgerald LF (1994) RAPE myths. Rev Psychol Women Q 18:133-164

66. Glick P, Fiske ST (2001) An ambivalent alliance: hostile and benevolent sexism as complementary justifications for gender inequality. Am Psychol 56:109-118. https://doi.org/10.1037// 0003-066x.56.2.109

67. Garos S, Beggan J, Kluck A, Easton A (2004) Sexism and pornography use: toward explaining past (null) results. J Psychol Hum Sex 16:69-96

68. Donelly B (2016) 'I am an artist': Man who makes child sex dolls for paedophiles. The Sydney Morning Herald

69. Bullock C (2016) Attractive, slavish and at your command: Is AI Sexist? BBC News, December 2016

70. Nunes KL, Pettersen C (2011) Competitive disadvantage makes attitudes towards rape less negative. Evol Psychol 9:509-521

71. TrueCompanion (2019) Roxxxy TrueCompanion Sex Robot. Available: http://www.truecompanion.com/shop/roxxxytrue companion-sex-robot/roxxxy/

72. Sparrow R (2017) Robots, rape, and representation. Int J Soc Robot 9:465-477. https://doi.org/10.1007/s12369-017-0413-z

73. Wagner C (2018) Sexbots: the ethical ramifications of social robotic's dark side. AI Matters 3:52-58. https://doi.org/10.1145/ 3175502.3175513

74. Jecker NSJ (2021) Nothing to be ashamed of: sex robots for older adults with disabilities. Med Ethics 47:26-32

75. Duwe G, Goldman RA (2009) The impact of prison-based treatment on sex offender recidivism: evidence from Minnesota. Sex Abuse A J Res Treat 21:279-307

76. Hanson RK, Bourgon G, Helmus L, Hodgson S (2009) A metaanalysis of the effectiveness of treatment for sexual offenders: risk, need, and responsivity. Public Safety Canada, Ontario Canada

77. Lösel F, Schmucker M (2005) The effectiveness of treatment for sexual offenders: a comprehensive meta-analysis. J Exp Criminol 1:117-146. https://doi.org/10.1007/s11292-004-6466-7

78. Eichenberg C, Khamis M, Hübner L (2019) The attitudes of therapists and physicians on the use of sex robots in sexual therapy: online survey and interview study. J Med Internet Res 21:e13853. https://doi.org/10.2196/13853

79. DiSalvo CF, Gemperle F, Forlizzi G, Kiesler S (2002) All robots are not created equal: The design and perception of humanoid robot heads. Proceedings of the 4th conference on Designing interactive systems: processes, practices, methods, and techniques, pp 321-326. https://doi.org/10.1145/778712.778756

80. Burleigh TJ, Schoenherr JR, Lacroix GL (2013) Does the uncanny valley exist? An empirical test of the relationship between eeriness and the human likeness of digitally created faces. Comput Hum Behav 29:759-771. https://doi.org/10. 1016/j.chb.2012.11.021

81. Rosenthal-von der Pütten AM, Krämer NC (2014) How design characteristics of robots determine evaluation and uncanny valley related responses. Comput Hum Behav 36:422-439. https://doi. org/10.1016/j.chb.2014.03.066

82. Crowne DP, Marlowe D (1964) The approval motive: studies in evaluative dependence. Wiley, New York

83. Salkind NJ (2010) Encyclopedia of research design. SAGE Publications, Thousand Oaks, CA

84. Crowne DP, Marlowe D (1960) A new scale of social desirability independent of psychopathology. J Consult Psychol 24:349-354

85. Reynolds WM (1982) Development of reliable and valid short forms of the Marlowe-Crowne social desirability scale. J Clin Psychol 38:119-125

86. Ballard R (1992) Short forms of the Marlowe-Crowne social desirability scale. Psychol Rep 71:1155-1160

87. Loo R, Thorpe K (2000) Confirmatory factor analyses of the full and short versions of the Marlowe-Crowne social desirability scale. J Soc Psychol 140:628-635

88. Andrews P, Meyer RG (2003) Marlowe-Crowne social desirability scale and short form C: forensic norms. J Clin Psychol 59:483-492 
89. Bumby KM (1996) Assessing the cognitive distortions of child molesters and rapists: developments and validation of the Molest and Rape scales. Sex Abuse-J Res Tr 8:37-54

90. Arkowitz S, Vess J (2003) An evaluation of the bumby Rape and Molest scales as measures of cognitive distortions with civilly committed sexual offenders. Sex Abuse-J Res Tr 15:237-249

91. Marshall WL, Marshall LE, Sachdev S, Kruger RL (2003) Distorted attitudes and perceptions, and their relationship with self-esteem and coping in child molesters. Sex Abuse-J Res Tr 15:171-181

92. Pervan S, Hunter M (2007) Cognitive distortions and social selfesteem in sexual offenders. Appl Psychol Crim Justice 3:75-91

93. Blokland A, Lussier P (2015) Sex offenders: a criminal career approach. Oxford UK, Wiley-Blackwell

94. Piquero AR, Farrington DP, Jennings WG, Diamond B, Craig J (2012) Sex offenders and sex offending in the Cambridge study in delinquent development: prevalence, frequency, specialization, recidivism, and (dis)continuity over the life-course. J Crime Justice 35:412-426. https://doi.org/10.1080/0735648X. 2012.688527

95. Lussier P, Cale J (2013) Beyond sexual recidivism: a review of the sexual criminal career parameters of adult sex offenders. Aggress Violent Behav 18:445-457. https://doi.org/10.1016/j. avb.2013.06.005

96. McCuish E, Lussier P, Corrado R (2016) Criminal careers of juvenile sex and nonsex offenders: evidence from a prospective longitudinal study. Youth Viol Juv Justice 14:199-224

97. Zara G, Veggi S (2018) I minorenni sessualmente abusanti tra solo-offending e co-offending. Uno studio esplorativo (Juvenile sex offenders between solo-offending and co-offending. An explorative study). Rassegna Ital di Criminol [Ital J Criminol] 4:262-274

98. Blumstein A, Cohen J, Roth JA, Visher CA (1986) Criminal careers and "career criminals" (vol. National Academy Press, Washington DC, I)

99. Zara G (2013) La validità incrementale della psico-criminologia e delle neuroscienze in ambito giuridico [The incremental validity of psychological criminology and neuroscience in the forensic setting]. Sistemi Intelligenti 2:311-338. https://doi.org/10.1422/ 75357

100. Piquero AR, Farrington DP, Blumstein A (2007) Key issues in criminal career research: new analyses of the Cambridge study in delinquent development. Cambridge University Press, Cambridge UK

101. Zara G, Farrington DP (2015) Criminal recidivism: Explanation, prediction and prevention. Routledge, Abingdon UK

102. Ireland JL, Ireland CA, Birch P (2018) Violent and sexual offenders: assessment, treatment, and management. Routledge, Abingdon

103. Hanson RK, Thornton D (1999) Static-99: improving actuarial risk assessments for sex offenders. User Report 99-02. Department of the Solicitor General of Canada, Ottawa

104. Hanson RK, Thornton D (2000) Improving risk assessments for sex offenders: a comparison of three actuarial scales. Law Hum Behav 24:119-136

105. Harris A, Phenix A, Hanson RK, Thornton D (2003) Static-99: coding rules revised. Department of the Solicitor General of Canada, Ottawa Canada

106. Brouillette-Alarie S, Babchishin KM, Hanson RK, Helmus, LM (2016) Latent constructs of the Static-99R and Static-2002R: A three-factor solution. Assessment 23:96-111

107. Babchishin KM, Hanson RK, Helmus L (2012) Even highly correlated measures can add incrementally to actuarial risk prediction. Assessment 19:442-461
108. Hanson RK, Thornton D (2003) Notes on the development of Static-2002 (Corrections Research User Report No. 2003-01). Department of the Solicitor General of Canada, Ottawa Canada

109. Helmus L, Thornton D, Hanson RK, Babchishin KM (2012) Improving the predictive accuracy of Static-99 and Static-2002 with older sex offenders: revised age weights. Sex Abuse J Res Treat 24:64-101

110. Hanson RK, Harris AJR, Scott TL, Helmus L (2007) Assessing the risk of sexual offenders on community supervision: the dynamic supervision project. Public Safety and Emergency Preparedness Canada, Ottawa Canada

111. Blasko BL, Jeglic EL (2014) Sexual offenders' perceptions of the client-therapist relationship: the role of risk. Sex Abuse A J Res Treat 28:271-290

112. DeSorcy DR, Olver ME, Wormith JS (2016) Working alliance and its relationship with treatment outcome in a sample of aboriginal and non-aboriginal sexual offenders. Sex Abuse A J Res Treat 28:291-313

113. Agresti A (2002) Categorical data analysis, 2nd edn. John Wiley \& Sons, New York, NY

114. Farrington DP, Loeber R (2000) Some benefits of dichotomization in psychiatric and criminological research. Crim Behav Ment Health 10:100-122. https://doi.org/10.1002/cbm.349

115. Zara G, Farrington DP (2020) Childhood risk factors for selfreported versus official life-course-persistent, adolescence-limited, and late onset offenders. Crim Justice Behav 47:352-368

116. Cohen J (1992) Statistical power analysis. Curr Dir Psychol Sci 1:98-101

117. Valverde S (2012) The modern sex doll-owner: a descriptive analysis. California State Polytechnic University. URL: https:// digitalcommons.calpoly.edu/theses/849/

118. Rothstein NJ, Connolly DH, de Visser EW, Phillips E (2021) Perception of infidelity with sex robots. Conference: proceedings of the $2021 \mathrm{ACM} / \mathrm{IEEE}$ international conference on humanrobot interaction. Boulder, CO. http://dx.doi.org/https://doi.org/ $10.1145 / 3434073.3444653$

119. Wiese E, Metta G, Wykowska A (2017) Robots as intentional agents: using neuroscientific methods to make robots appear more social. Front Psychol 8:1663. https://doi.org/10.3389/fpsyg. 2017.01663

120. Kessler R, Birnbaum H, Bromet E, Hwang I, Sampson N, Shahly $\mathrm{V}$ (2010) Age differences in major depression: results from the national comorbidity survey replication (ncs-r). Psychol Med 40:225-237. https://doi.org/10.1017/s0033291709990213

121. Beutler LE, Someah K, Kimpara S, Miller K (2016) Selecting the most appropriate treatment for each patient. Int J Clin Health Psychol 16:99-108. https://doi.org/10.1016/j.ijchp.2015.08.001

122. National Research Council (US) Panel on handling missing data in clinical trials. The prevention and treatment of missing data in clinical trials. National Academies Press (US), Washington (DC), 2010. Appendix A, clinical trials: overview and terminology. Available from: https://www.ncbi.nlm.nih.gov/books/NBK20 9903/

123. Devillers L (2017) Des robots et des hommes - mythes, fantasmes et réalités. Plon, Paris

124. Levy D (2009) Love and sex with robots: the evolution of human robot relationships. Duckworth Overlook, London

125. Seto MC, Eke AW (2005) The criminal histories and later offending of child pornography offenders. Sex Abuse 17:201-210

126. Seto MC (2018) Pedophilia and sexual offending against children: theory, assessment, and intervention, 2nd edn. American Psychological Association, Washington, DC

127. Hanson RK, Bussiere MT (1998) Predicting relapse: a metaanalysis of sexual offender recidivism studies. J Consult Clin Psychol 66:348-362 
128. Hanson RK, Morton-Bourgon KE (2005) The characteristics of persistent sexual offenders: a meta-analysis of recidivism studies. J Consult Clin Psychol 73:1154-1163

129. Derrick JL, Gabriel S, Hugenberg K (2009) Social surrogacy: how favoured television programs provide the experience of belonging. J Exp Soc Psychol 45:352e362

130. Dubé S, Anctil D (2020) Foundations of erobotics. Int J Soc Robot. https://doi.org/10.1007/s12369-020-00706-0

131. Laws DR, Gress CLZ (2004) Seeing things differently: The viewing time alternative to penile plethysmography. Leg Crim Psychol 9:183-196. https://doi.org/10.1348/1355325041719338

132. Parsons TD, Phillips AS (2016) virtual reality for psychological assessment in clinical practice. Pract Innov 1:197-217

133. Freilone F, Dotta M, Veggi S, Zara G (2018) La psicologia delle relazioni sintetiche: affettività e sessualità 'alternative' con i sexbot (The psychology of synthetic relationships: alternative sexuality and affectivity with sexbots) NEU Rivista scientifica di formazione infermieristica in neuroscienze [NEU Scientific Journal of Nursing and Neuroscience] 3:55-67. ISSN 1723-2538

134. Fromberger P, Jordan K, Müller JL (2018) Virtual reality applications for diagnosis, risk assessment and therapy of child abusers. Behav Sci Law 36:235-244. https://doi.org/10.1002/bsl.2332

135. Renaud P, Rouleau J, Proulx J, Trottier D (2010) Virtual characters designed for forensic assessment and rehabilitation of sex offenders: standardized and made-to-measure. JVRB 7:1-10
136. Kaplan F (2004) Who is afraid of the humanoid? Investigating cultural differences in the acceptance of robots. Int J Hum Robot $1: 465-480$

137. Johnson DJ, Verdicchio M (2020) Constructing the meaning of humanoid sex robots. Int J Soc Robot 12:415-424. https://doi. org/10.1007/s12369-019-00586-z

138. Miller J, Trocchio S (2017) Risk/Need assessment tools and the criminal justice bureaucrat. In: Taxman FS (ed) Handbook on risk and need assessment. Theory and practice. Routledge, New York, pp 378-405

139. Jung S, Zara G (2018) Diniego e resistenza al trattamento negli aggressori sessuali [Treating sex offenders who are resistant or in denial]. In Zara G (ed) Il diniego nei sex offender. Dalla valutazione al trattamento [Denial in sex offenders. From assessment to treatment]. Raffaello Cortina, Milano, pp 111-127

Publisher's Note Springer Nature remains neutral with regard to jurisdictional claims in published maps and institutional affiliations. 